\title{
Distinct Firing Patterns of Neuronal Subtypes in Cortical Synchronized Activities
}

\author{
Yasuo Kawaguchi \\ Division of Cerebral Circuitry, National Institute for Physiological Sciences, Okazaki, 444-8585, Japan, and Laboratory for \\ Neural Circuits, Bio-Mimetic Control Research Center, The Institute of Physical and Chemical Research (RIKEN), Nagoya, \\ 463-0003, Japan
}

Cortical neurons, especially GABAergic interneurons, are composed of very diverse subtypes. It remains to be investigated whether each subtype shows a unique firing pattern during the synchronized activities generated by the intracortical circuit. By lowering extracellular $\mathrm{Mg}^{2+}$ in vitro, we induced NMDA receptor-dependent spontaneous activities in the rat frontal cortex at $30^{\circ} \mathrm{C}$. After a series of spontaneous depolarization shifts, the long bursts occurred. The long bursts were composed of initial discharges and fast run-like potentials (FRLP) (4-10 Hz). Large inhibitory currents were induced at the initial discharge. After the strong inhibition decreased, the FRLP started. However, the periodical inhibition survived during the FRLP. At each phase of the synchronized activities, cortical neuron types exhibited distinct firing patterns. Pyramidal cells increased firing frequency periodically up to $\sim 25-55 \mathrm{~Hz}$ during the FRLP cycles. Fast-spiking (FS) cells fired at the highest

Compared with excitatory pyramidal cells, cortical inhibitory interneurons are highly diverse in morphological, chemical, and physiological characteristics (Ramón y Cajal, 1911; DeFelipe, 1997; Kawaguchi and Kubota, 1996, 1998; Cauli et al., 2000; Gupta et al., 2000). To understand the organizing principles of cortical circuits, it is necessary to define functional subtypes of inhibitory interneurons and reveal their synaptic connection rules within the columnar circuit (White, 1989; Amitai and Connors, 1995; Somogyi et al., 1998; Jones, 2000). Recent attempts to define functional subsets of cortical interneurons have yielded various contradictory ideas (Kawaguchi and Kubota, 1997; Miles, 2000). In the hippocampus, the simplest of all cortices, subsets of inhibitory cells defined by morphology, electrophysiology, and expression of neurotransmitter receptors, do not coincide, suggesting that either there may be a very large number of subtypes of inhibitory cells or that each cell may be different (Parra et al., 1998). In the neocortex, cortical inhibitory interneurons can be grouped into dozens of functionally related classes according to the discharge pattern, anatomy, and kinetics of synaptic transmission (Gupta et al., 2000). Several GABAergic cell types have been

\footnotetext{
Received May 3, 2001; revised June 28, 2001; accepted June 29, 2001.

This work was supported by grants-in-aid for scientific research from the Ministry of Education, Culture, Sports, Science, and Technology of Japan, The Naito Foundation, and Toyota Physical and Chemical Research Institute. I thank Drs. Y. Kubota and S. Kondo for discussion, Dr. A. Agmon for comments on this manuscript, and Y. Ito for technical assistance.

Correspondence should be addressed to Yasuo Kawaguchi, Division of Cerebral Circuitry, National Institute for Physiological Sciences, Myodaiji, Okazaki, 4448585, Japan. E-mail: yasuo@nips.ac.jp.

Copyright (C) 2001 Society for Neuroscience $\quad 0270-6474 / 01 / 217261-12 \$ 15.00 / 0$
}

frequency in the initial discharge, up to $400 \mathrm{~Hz}$, and could continue firing faster than $200 \mathrm{~Hz}$ for several seconds. In the FRLP, the firing frequency of FS cells rhythmically increased up to $150 \mathrm{~Hz}$. In contrast, large cholecystokinin basket cells fired, very similarly to pyramidal cells, at each phase. Somatostatin and vasoactive intestinal polypeptide cells fired faster than pyramidal cells at the initial discharge, but showed the similar firings to pyramidal cells during the FRLP. The firing patterns of cortical neurons are not only determined by the strength and temporal pattern of synchronized inputs but also strongly dependent on the neuronal subtype with specific physiological, chemical, and morphological characteristics.

Key words: frontal cortex; nonpyramidal cell; interneuron; GABA; parvalbumin; somatostatin; cholecystokinin; VIP; fastspiking cell

identified on the basis of their firing response to a depolarizing current, axon arborization pattern, synaptic connections, and co-expression of neuroactive substances and receptors in the rat frontal cortex (Kawaguchi, 1997; Kawaguchi and Kubota, 1998; Kawaguchi and Shindou, 1998). For functional understanding, these diverse types of interneurons were identified by firing patterns to current injection (Gupta et al., 2000; Pike et al., 2000); it is important to reveal how each subtype fires during the oscillatory or seizure activities, in comparison with pyramidal cells.

In contrast to the intact cortex in vivo, neuronal spontaneous firing is low, and the network activities are almost absent in cortical slices in vitro. By lowering extracellular $\mathrm{Mg}^{2+}$, NMDA receptor-dependent synchronized seizures can be induced in vitro, including epochs of 4-10 Hz synchronized activity (Thomson and West, 1986; Hegstad et al., 1989; Silva et al., 1991; Flint and Connors, 1996). However, firing patterns of cortical neuron types have not been investigated in this seizure model. In the present experiments, we compared the firing patterns among pyramidal cells and GABA cell subtypes during several synchronized activities induced by omission of extracellular $\mathrm{Mg}^{2+}$. We found that neuronal firing patterns are dependent both on the phase of synchronized excitation or oscillation and on the cortical neuron type with specific physiological, chemical, and morphological characteristics.

\section{MATERIALS AND METHODS}

Slice preparation. The experiments were performed on young Wistar rats (19-23 d postnatal). Animals were deeply anesthetized with ether and decapitated. The brains were quickly removed and submerged in ice-cold 


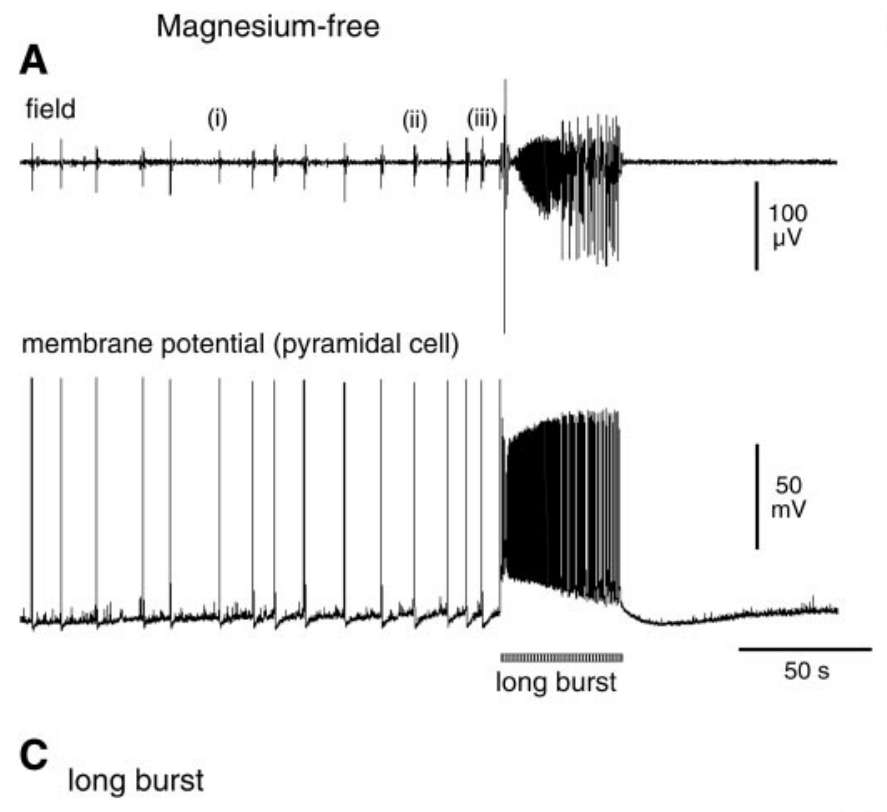

B depolarization shift
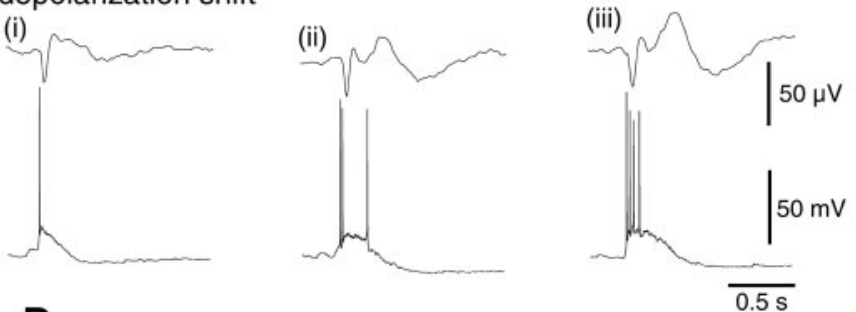

D fast run-like potential (FRLP)

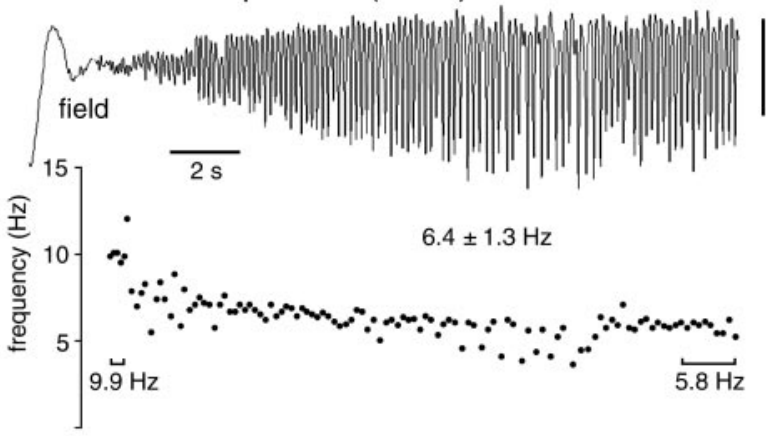

E field, m.p.

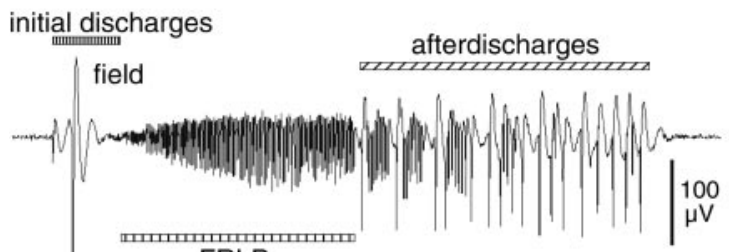

FRLP

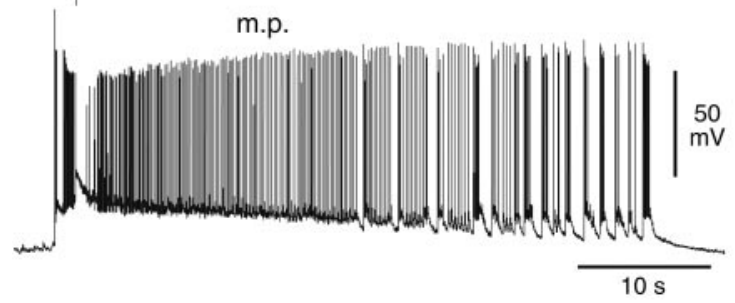

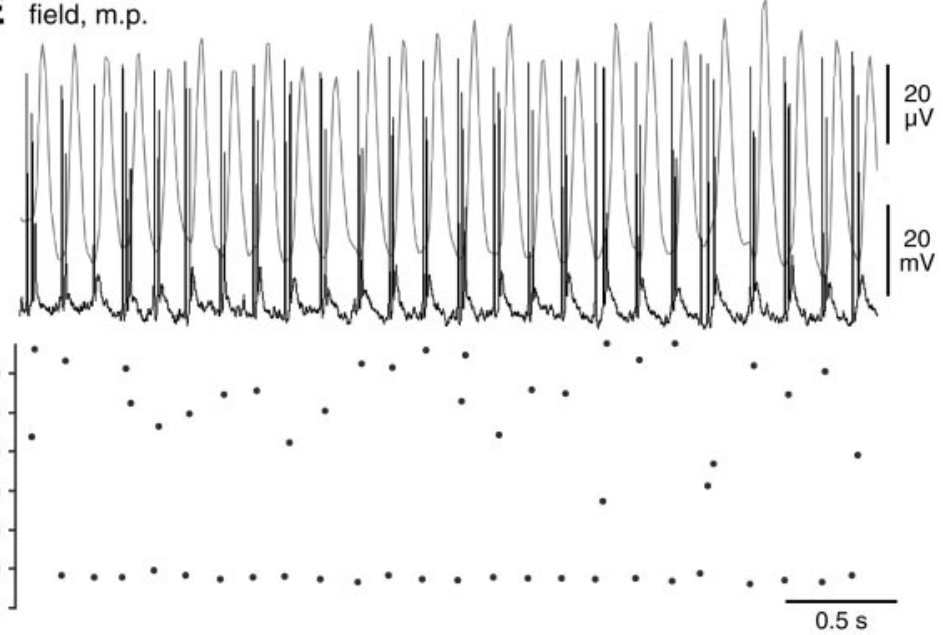

Figure 1. Omission of $\mathrm{Mg}^{2+}$ from the external solution induced two types of spontaneous depolarizations in the rat frontal cortex in vitro. A-C, A membrane potential of a pyramidal cell (bottom) and a field potential recorded nearby (top). Resting potential, $-65 \mathrm{mV} . A, \mathrm{In}$ the $\mathrm{Mg}{ }^{2+}$-free solution, spontaneous depolarizations of pyramidal cells with spike firing appeared and gradually increased (Bi, Bii, and Biii), which accompanied field potential change, resulting in a long-lasting depolarization (long burst). $C$, The long burst was composed of several phases: (1) initial strong depolarization inducing many spikes with the highest frequency (initial discharges); (2) rhythmic depolarizations with frequencies from 6 to $10 \mathrm{~Hz}$ for several seconds after the initial discharges [fast run-like potentials $(F R L P)]$; (3) several strong depolarizations recurring with lower frequencies (afterdischarges). D, The FRLP (expansion of that shown in $C$ ) started at $9.9 \mathrm{~Hz}$ (cycle frequency; average of first 5 cycles) and increased the peak-to-peak amplitude of the field potential, ending at $5.8 \mathrm{~Hz}$ (average of the last 10 cycles). E, A pyramidal cell discharged spikes (black) in response to rhythmic depolarizations with the same periodicity as the field potential of FRLP ( gray).

physiological Ringer's solution. Sections (200 $\mu \mathrm{m}$ thick) of frontal cortex were cut, immersed in a buffered solution consisting of (in $\mathrm{mM}$ ): $\mathrm{NaCl}$ 124.0, $\mathrm{KCl} 3.0, \mathrm{CaCl}_{2} 2.4, \mathrm{MgCl}_{2}$ 1.2, $\mathrm{NaHCO}_{3} 26.0, \mathrm{NaH}_{2} \mathrm{PO}_{4}$ 1.0, glucose 10.0 , and aerated with a mixture of $95 \% \mathrm{O}_{2} / 5 \% \mathrm{CO}_{2}$. Membrane potentials of cells in the frontal cortex (medial agranular cortex and anterior cingulate cortex) were recorded in a whole-cell mode, and unit spike discharges were recorded in a loosely cell-attached mode at $30^{\circ} \mathrm{C}$ using a $40 \times$ water immersion objective. To increase the excitability and the NMDA receptor activation, $\mathrm{Mg}^{2+}$ and $\mathrm{Ca}^{2+}$ ion concentration in the bathing solution was reduced to zero and $1.2 \mathrm{~mm}$, respectively. The reduction was not compensated by replacement with other divalent cations.

Electrophysiological recording. The electrode solution for the currentclamp recording consisted of (in $\mathrm{mM}$ ): potassium methylsulfate $115, \mathrm{KCl}$ 5.0, EGTA 0.5, $\mathrm{MgCl}_{2}$ 1.7, ATP 4.0, GTP 0.3, HEPES 8.5, and biocytin 17. The $\mathrm{pH}$ of the solution was adjusted to 7.3 with $\mathrm{KOH}$, and the osmolarity was $\sim 280-290 \mathrm{mOsm}$. Current-clamp recordings were made in a fast current-clamp mode of EPC9/dual (Heka Elektronik, Lambre-
cht/Pfalz, Germany). For the voltage-clamp recording (a whole-cell mode of EPC9), micropipettes were filled with pipette solution consisting of (in $\mathrm{mM}$ ): cesium methanesulfonate $120, \mathrm{KCl}$ 5.0, EGTA 10.0, $\mathrm{CaCl}_{2}$ 1.0, $\mathrm{MgCl}_{2} 2.0$, ATP 4.0, GTP 0.3, HEPES 8.0, liodocaine $N$-ethyl bromide (QX314) 5.0, and biocytin 20. The $\mathrm{pH}$ of the solution was adjusted to 7.3 with $\mathrm{CsOH}$, and the osmolarity was $295 \mathrm{mOsm}$. Field potential and single cell firing were recorded by electrodes filled with the external solution. Field potentials were passed through a filter between 0.8 and $16 \mathrm{~Hz}$. Unit spikes were identified from potentials recorded between 0.4 and $2 \mathrm{kHz}$. Unpaired $t$ tests were performed to compare values between cell types.

Drugs were applied by replacing the solution superfusing the slice with one containing a set concentration. D-2-amino-5-phosphonovaleric acid (D-APV) (25 $\mu \mathrm{M})$ and 2,3-dioxo-6-nitro-1,2,3,4-tetrahydrobenzo[f]quinoxaline-7-sulfonamide disodium (NBQX) $(10 \mu \mathrm{M})$ were obtained from Tocris (Bristol, UK), and (-)-bicuculline methiodide $(10 \mu \mathrm{M})$ was obtained from Sigma (St. Louis, MO).

Antibodies. A monoclonal antibody raised against cholecystokinin 


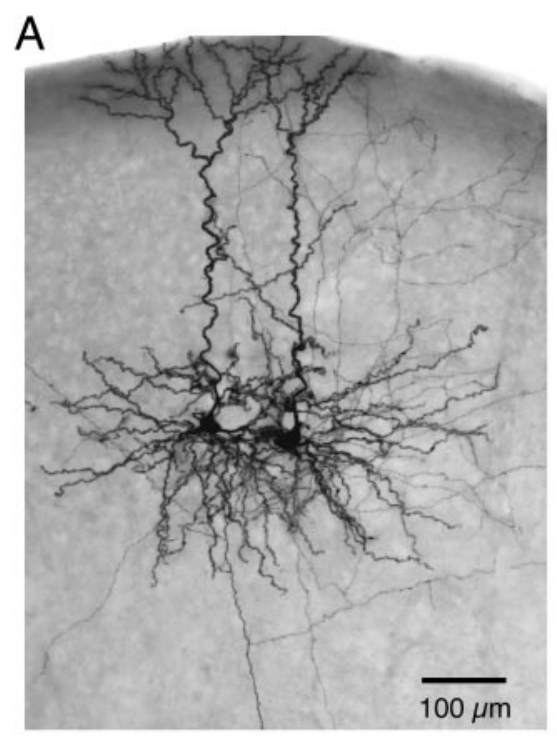

D

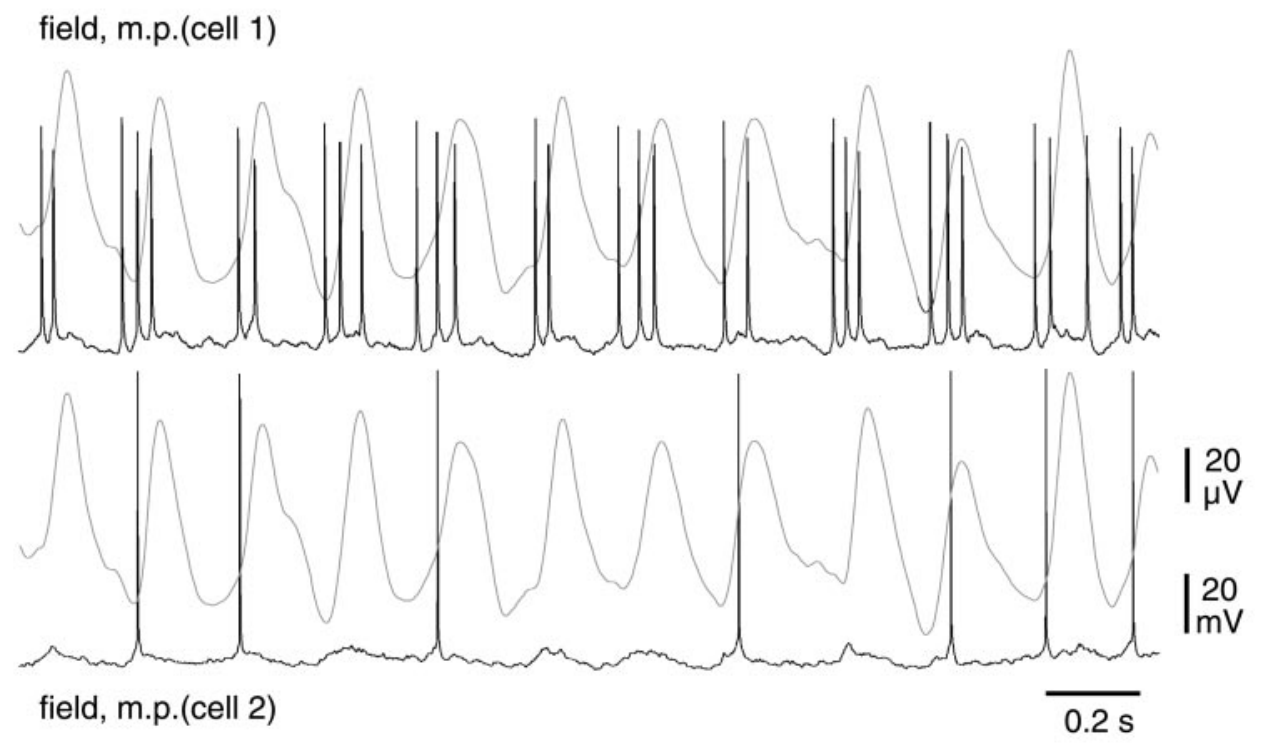

B

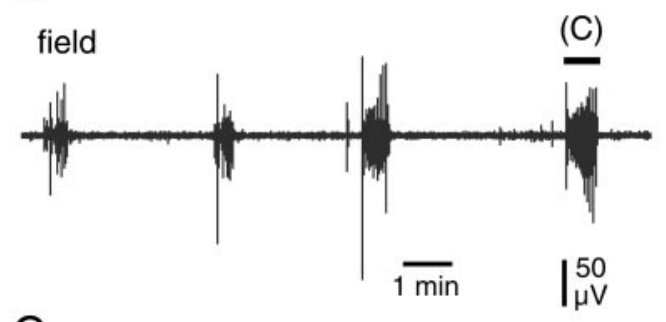

m.p.(cell1)

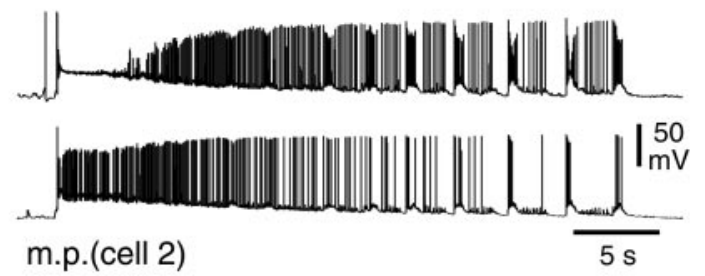

Figure 2. Synchronization of depolarizations between pyramidal cells during the long burst. $A$, Simultaneously recorded and intracellularly stained pyramidal cells. $B-C$, The depolarizations in two pyramidal cells occurred synchronously during the long burst; the field potential of that is shown in $B$. Resting potential, $-57 \mathrm{mV}$ in cell 1 and $-64 \mathrm{mV}$ in cell 2. $D$, Membrane potentials (m.p.) of two pyramidal cells during the FRLP, shown with the field potential (gray trace). In the top and bottom traces, membrane potentials of two pyramidal cells (cells 1 and 2, respectively) are shown in black with the field potential. Small depolarizing potentials occurred in pyramidal cells during the FRLP. Cell 1 fired two or three spikes on each depolarization, whereas cell 2 fired one or none. Both cells fired at the same phase of the field cycle. Intervals from each spike of cell 2 to the nearest spike of cell 1 in $D$ are $5.62 \pm 5.05$ msec.
(CCK)/Gastrin (monoclonal antibody 28.2) was provided by Antibody/ RIA Core, CURE/Gastroenteric Biology Center, University of California-Los Angeles. A rat monoclonal antibody against somatostatin (MAB354) was purchased from Chemicon (Temecula, CA). A rabbit antiserum against vasoactive intestinal polypeptide (VIP) (catalog \#20077) was obtained from Incstar (Stillwater, MN). For investigation of parvalbumin, a mouse monoclonal antibody (P-3171) from Sigma and a rabbit antiserum (PV-28) from Swant (Bellinzona, Switzerland) were used.

Histological procedures for immersion-fixed slices. Tissue slices containing biocytin-loaded cells were fixed by immersion in $4 \%$ paraformaldehyde and $0.2 \%$ picric acid in $0.1 \mathrm{~m}$ sodium phosphate buffer. Each slice was further treated by one of the following two procedures.

(1) Some slices were incubated with avidin-biotin-peroxidase complex (1:100; Vector Laboratories, Burlingame, CA) in $0.05 \mathrm{M}$ Tris HClbuffered saline (TBS) containing 0.1\% Triton X-100 (TX) for $4 \mathrm{hr}$. After washing in TBS, the slices were reacted with $3,3^{\prime}$-diaminobenzidine tetrahydrochloride (DAB) $(0.05 \%)$ and $\mathrm{H}_{2} \mathrm{O}_{2}(0.003 \%)$ in Tris- $\mathrm{HCl}$ buffer.

(2) The other slices were processed for single or double fluorescence immunohistochemistry. The slices were incubated with the primary antibodies in TBS containing 2\% bovine serum albumin (BSA), $10 \%$ normal goat serum (NGS), and $0.5 \%$ TX. After washing in TBS, they were incubated in fluorescent secondary antibodies in TBS containing
BSA, NGS, and TX for $4 \mathrm{hr}$, followed by incubation with a sulfonated derivative of 7-amino-4-methylcoumarin-3-acetic acid-conjugated streptavidin (1:600; S-6364; Molecular Probes, Eugene, OR) in TBS for $2 \mathrm{hr}$. After examination for fluorescence, the slices were incubated with avidin-biotin-peroxidase complex in TBS and reacted with DAB and $\mathrm{H}_{2} \mathrm{O}_{2}$ in Tris- $\mathrm{HCl}$ buffer.

\section{RESULTS}

\section{Depolarization shifts followed by long bursts in $\mathrm{Mg}^{2+}$-free solution}

When frontal cortex slices were bathed in solutions with nominally zero $\mathrm{Mg}^{2+}$ concentrations, there occurred spontaneous depolarizations in pyramidal cells and the corresponding change of field potentials, indicating synchronized activities in the local circuits (Fig. 1 $A, B$ ). These spontaneous depolarizations were termed "depolarization shifts" in this paper. These depolarizations and the field potentials gradually became large enough to produce several spikes in pyramidal cells (Fig. 1B). In 10-20 min bathing in $\mathrm{Mg}^{2+}$-free solution, larger field potentials and strong depolarizations with many spikes appeared abruptly, followed by 
Figure 3. Spike discharges of pyramidal cells during the FRLP. A, Unit spike discharges were recorded from two pyramidal cells (unit 1 and unit 2) with the field potential during FRLP. $B$, Rhythmic spike firings occurred in cycles during FRLP, shown in phase histograms ( field $\rightarrow$ unit 1 and field $\rightarrow$ unit 2; one cycle of FRLP $=360$ degrees). Both cells increased firings at the similar phase of the cycle. $C$, The autocorrelograms (unit $1 \rightarrow$ unit 1 and unit $2 \rightarrow$ unit 2) showed firing intervals of $\sim 40 \mathrm{msec}$ in both cells. $D$, The spike discharges were correlated between two pyramidal cells (unit $1 \rightarrow$ unit 2 ). Data are mean \pm SD.
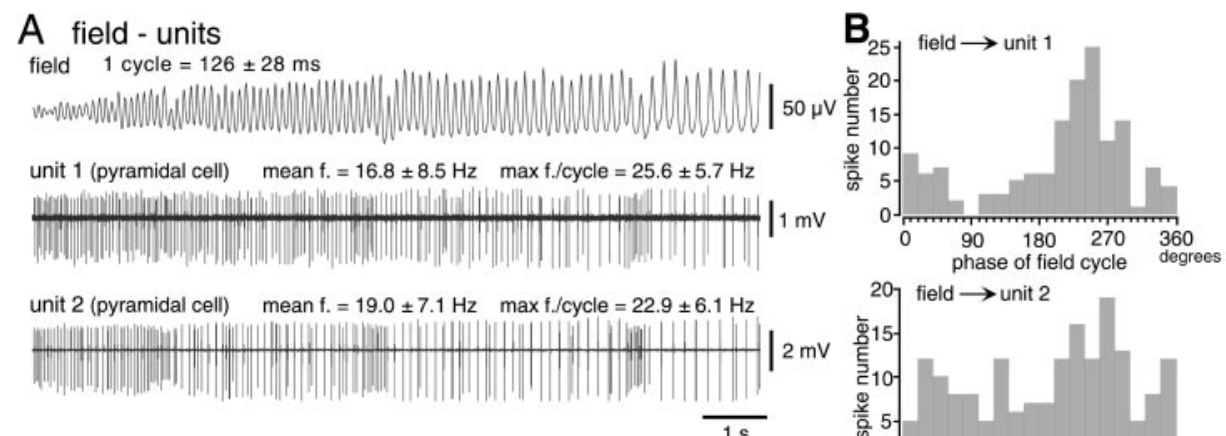

C
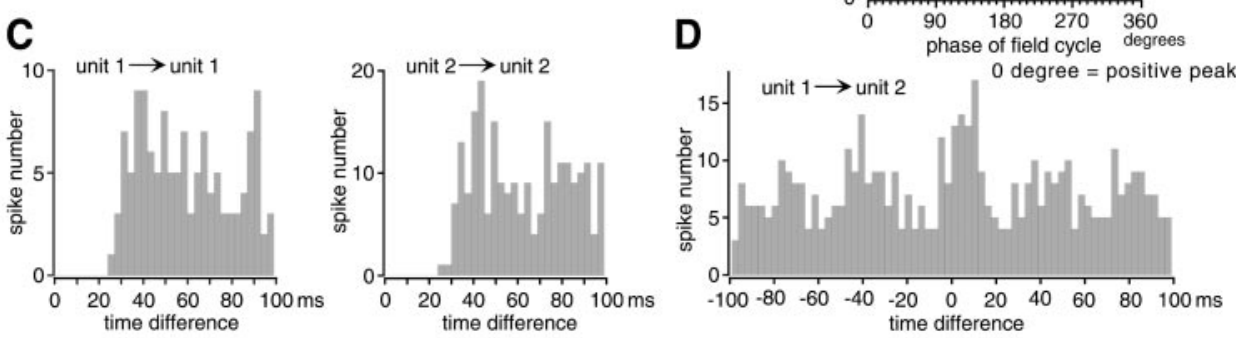

A

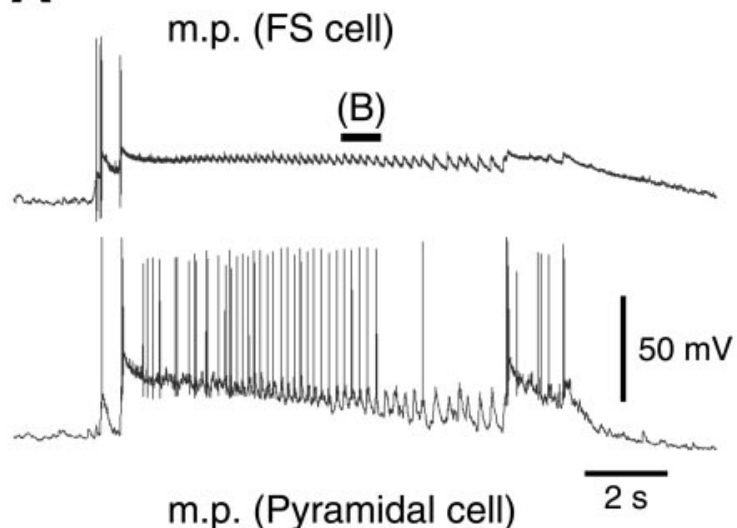

C

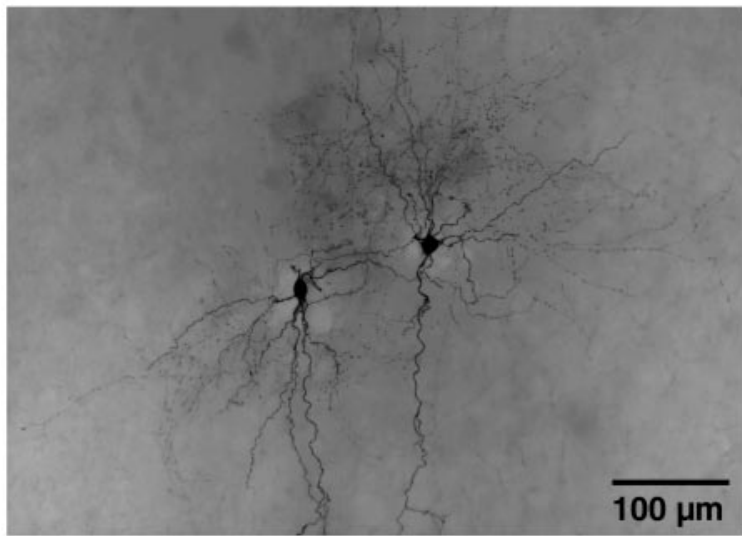

B m.p. (FS cell)

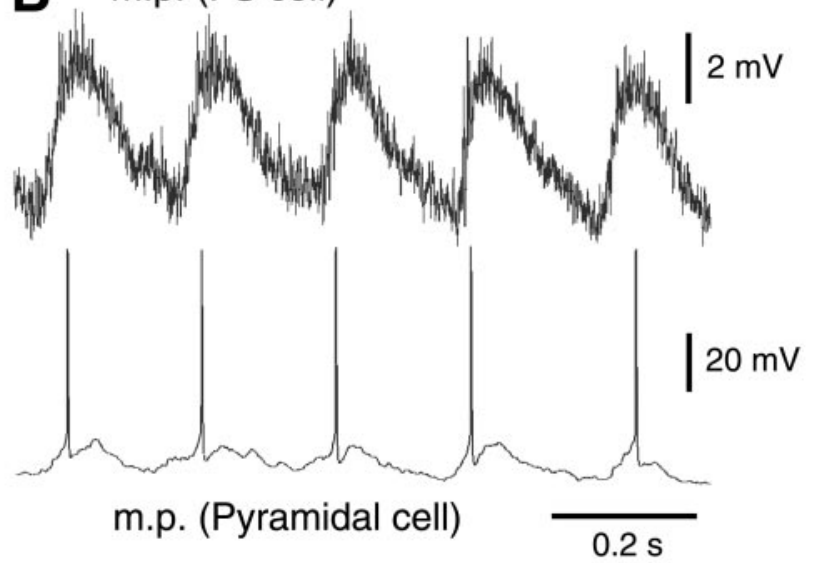

D m.p. (FS cell 1)
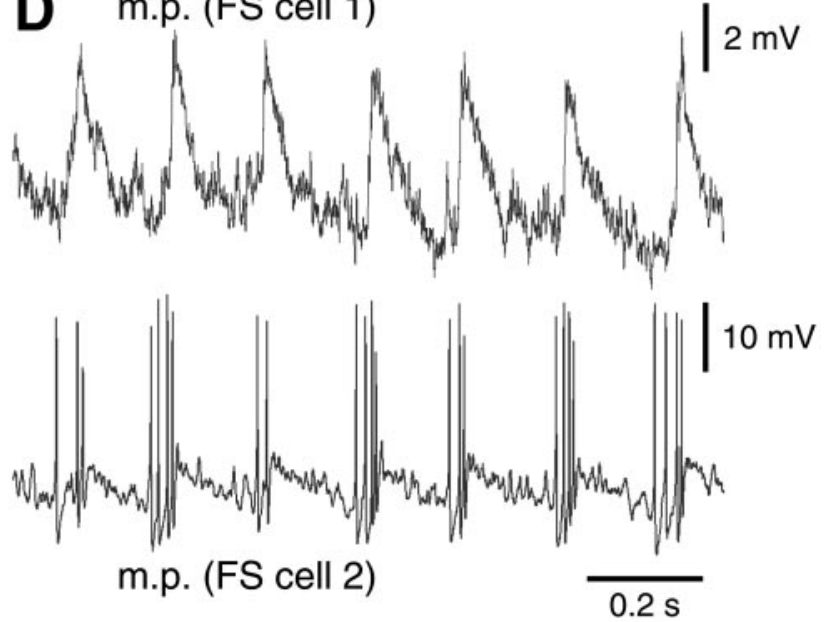

Figure 4. Fast-spiking cells showed long bursts and membrane potential (m.p.) fluctuations during FRLP synchronously with pyramidal cells. $A$, The long burst of an FS cell coincided with that of a pyramidal cell. Firing of this FS cell ceased during the FRLP because of spike inactivation. Resting potential is $-58 \mathrm{mV}$ in the FS cell and $-67 \mathrm{mV}$ in the pyramidal cell. $B$, The changing patterns of FRLP were synchronous between the FS and pyramidal cells shown in $A$. $C$, Two intracellularly stained FS cells recorded simultaneously, shown in $D$. $D$, Depolarizations during FRLP occurred simultaneously between two FS cells. Spike firing of FS cell 1 was inactivated, but spike firing of FS cell 2 was not. 


\section{Depolarization shifts}

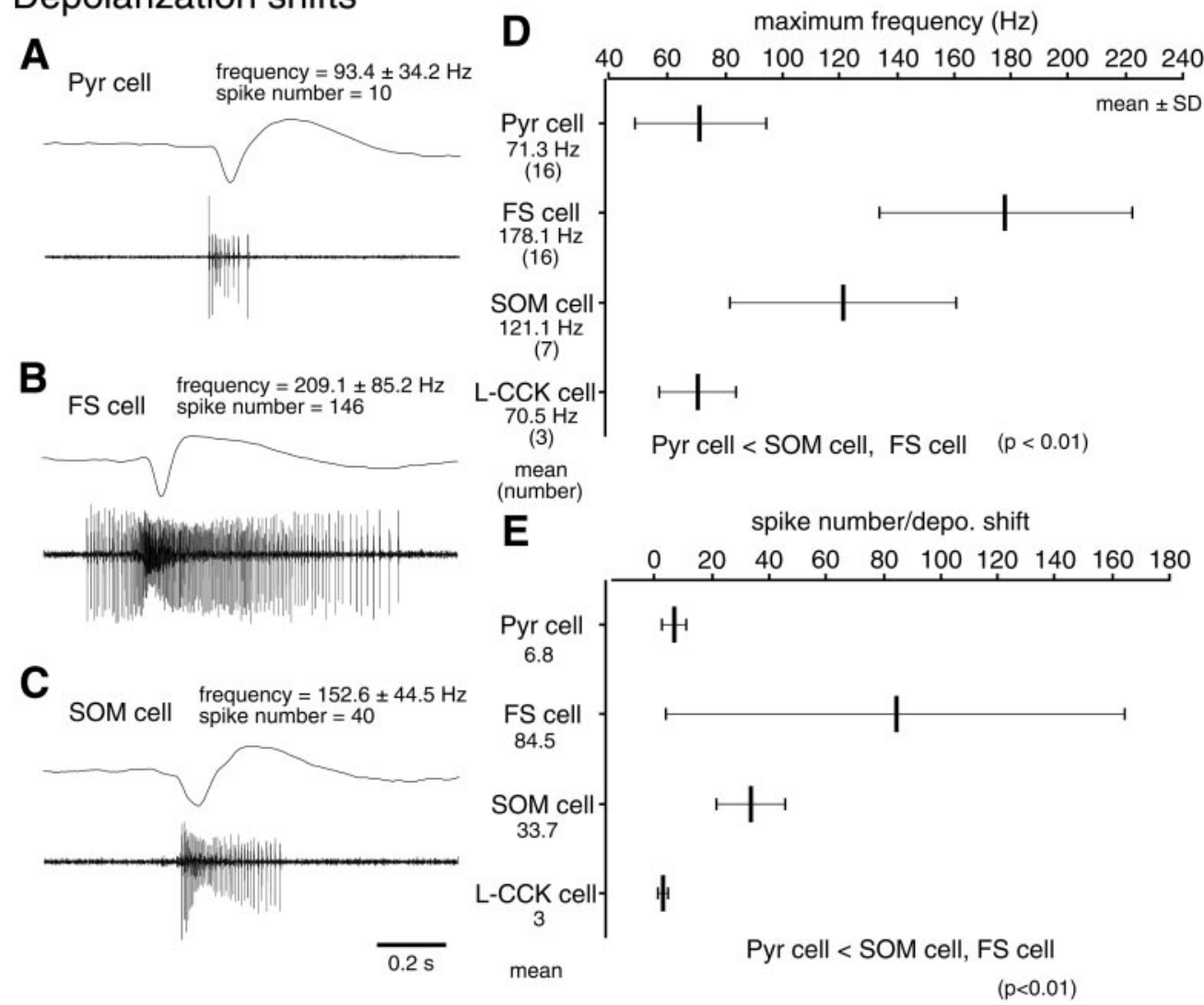

Figure 5. Firing patterns of cortical neuron types during depolarization shifts. $A-C$, Field potentials and extracellularly recorded units of pyramidal $(P y r)$, fast-spiking $(F S)$, and somatostatin $(S O M)$ cells during depolarization shifts before the transition to long bursts. Average spike frequencies during these depolarization shifts were written. Data are mean \pm SD. $D, E$, Maximum spike frequency and spike number generated during a depolarization (depo.) shift for pyramidal cells (16 shifts from 11 cells), FS cells (16 shifts from 12 cells), somatostatin cells ( 7 shifts from 7 cells), and large CCK $(L-C C K)$ cells (3 shifts from 3 cells). FS and somatostatin cells fired more spikes at higher frequency than pyramidal cells. long-lasting depolarizations (Fig. $1 A, C$ ). These persistent depolarizations are termed "long bursts." The depolarization shift of membrane potentials in pyramidal cells lasted for $0.64 \pm 0.22 \mathrm{sec}$ ( $n=7$ cells; average of three depolarization shifts just before the long burst). The intervals between depolarization shifts were $11.9 \pm 3.7 \mathrm{sec}(n=18$ slices; measured from three intervals between negative peaks in field potentials of depolarization shifts just before the long burst). Once the first burst occurred, long bursts appeared repeatedly (Fig. $2 A$ ) (interval $=321.6 \pm 121.5$ sec; $n=14$ slices).

The long burst was composed of three phases (Fig. 1C): (1) initial strong depolarizations accompanying spikes with the highest frequency, termed "initial discharges"; (2) rhythmic depolarizations at $\sim 6-10 \mathrm{~Hz}$ on relatively steady depolarizations, which were similar to fast runs observed in vivo (Steriade et al., 1998), termed "fast run-like potentials" (FRLPs); and (3) several slowrhythmic strong depolarizations, termed "afterdischarges." FRLP started with smaller amplitudes at higher frequency (first five cycles, $9.92 \pm 1.94 \mathrm{~Hz} ; n=42$ slices) and finished with larger ones at lower frequency (final 10 cycles, $6.04 \pm 1.34 \mathrm{~Hz}$; total waves, $7.76 \pm 1.44 \mathrm{~Hz}$; FRLP duration, $9.65 \pm 4.94 \mathrm{sec}$; number of waves, $73.0 \pm 36.6$ ) (Fig. 1D). During the FRLP, pyramidal cells were depolarized periodically at the same frequency as the field potential, accompanying spike discharges (Fig. 1E).

The depolarization shifts and long bursts in $\mathrm{Mg}^{2+}$-free solution disappeared by application of an antagonist for NMDA receptors, $25 \mu \mathrm{M}$ D-APV (four slices; data not shown), but persisted in the presence of a non-NMDA receptor blocker, $10 \mu \mathrm{M}$ NBQX (five slices; data not shown) (Thomson and West, 1986; Hegstad et al., 1989; Silva et al., 1991; Flint and Connors, 1996).

\section{Synchronized depolarizations among cortical cells during FRLP}

Simultaneous recordings of membrane potentials from two pyramidal cells with the field potential revealed that the depolarization shifts and long bursts were induced synchronously in cortical cells nearby (Fig. $2 A--C$ ). During the FRLP, pyramidal cells were depolarized synchronously at the same frequency as the field potential change (Fig. 2D). Spike discharges increased in frequency repeatedly, according to the FRLP cycle. Pyramidal cells fired spikes at a maximum frequency of $\sim 25-55 \mathrm{~Hz}$ during FRLP cycles. Spike firings from two pyramidal cells occurred on the similar phase of the FRLP cycles (Figs. $2 D, 3 A, B$ ). Some spikes from one pyramidal cell occurred within $5 \mathrm{msec}$ from those of another cell during the partial period of the FRLP (Fig. 2D). Small depolarizations occurred on the periodical fluctuations of the membrane potentials with the FRLP cycle. Cross-correlation of unit spikes recorded extracellularly from two pyramidal cells during FRLP suggests that the tendency of synchronized firing during FRLP (Fig. 3C,D). Peak interval of the cross-correlogram was $32.8 \pm 3.3 \mathrm{msec}$ (mean $\pm \mathrm{SD}$; eight pairs).

The long bursts were also found in GABAergic nonpyramidal cells (Fig. 4A) [15 fast-spiking (FS) cells and 3 somatostatin cells; see below]. Rhythmic depolarizations during the FRLP were synchronous between pyramidal and FS cells (four pairs) (Fig. $4 B$ ), between pyramidal and somatostatin cells (one pair), and between FS cells (one pair) (Fig. 4C,D). These indicate that nonpyramidal cells exhibit the similar changes of membrane potentials to that of pyramidal cells during the long burst. 


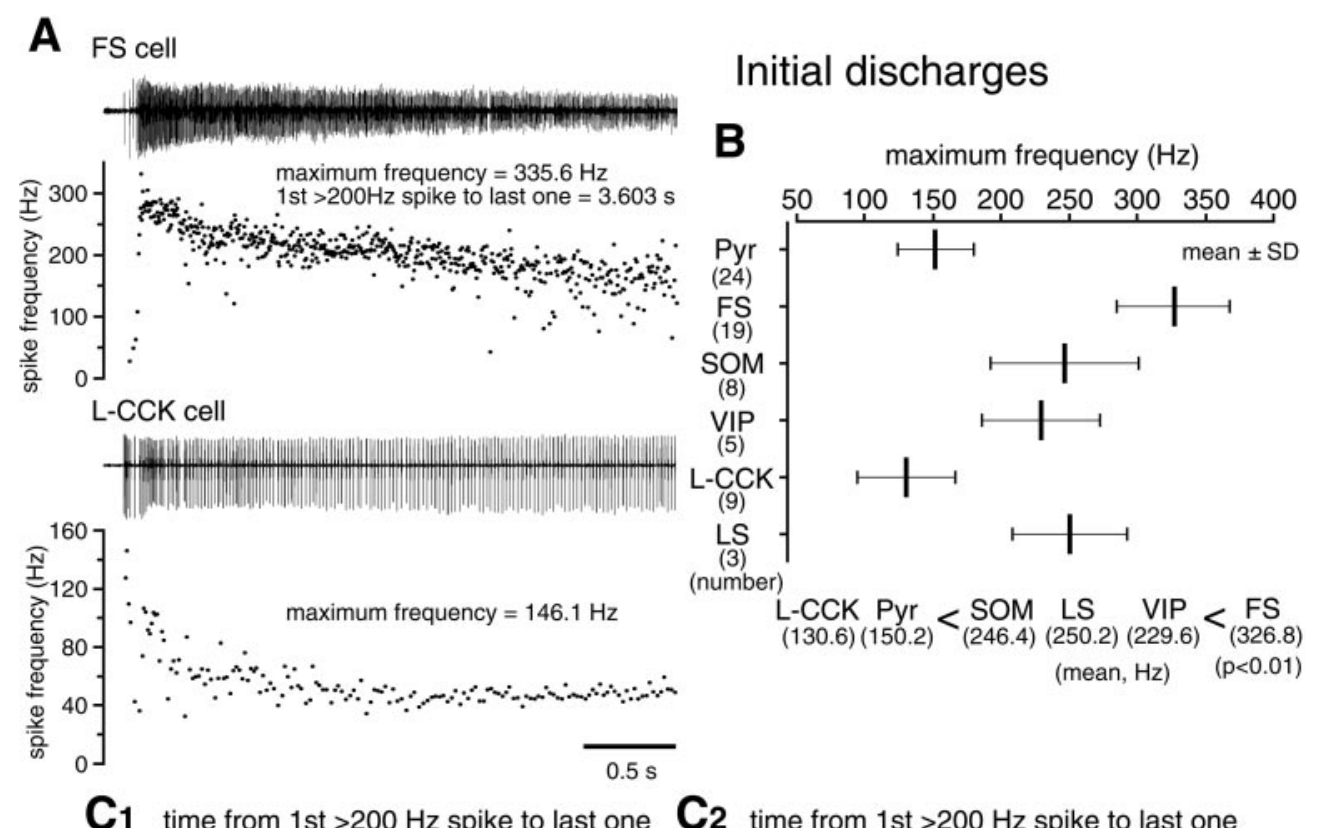

Figure 6. Firing patterns of cortical neuron types during initial discharges. $A$, Unit spike discharges and instantaneous spike frequencies during initial discharges for an FS cell and a large CCK $(L-C C K)$ cell. $B$, Maximum spike frequency generated during initial discharges for pyramidal (Pyr) cells (24 discharges from 19 cells), FS cells (19 discharges from 13 cells), somatostatin (SOM) cells (8 discharges from 7 cells), VIP cells (5 discharges from 5 cells), L-CCK cells (8 discharges from 5 cells), and late-spiking $(L S)$ cells (3 discharges from 2 cells). FS cells fired spikes with higher frequency than other types, whereas pyramidal and large CCK cells fired spikes with lower frequency. $C$, Time from the first spike with frequency higher than $200 \mathrm{~Hz}$ to the last one with frequency higher than $200 \mathrm{~Hz}$ during initial discharges. $C 2$ is expanded from the marked portion in C1. FS cells sometimes fired spikes with frequency higher than $200 \mathrm{~Hz}$ for several seconds. Pyramidal and large CCK cells did not fire spikes with frequency higher than $200 \mathrm{~Hz}$.

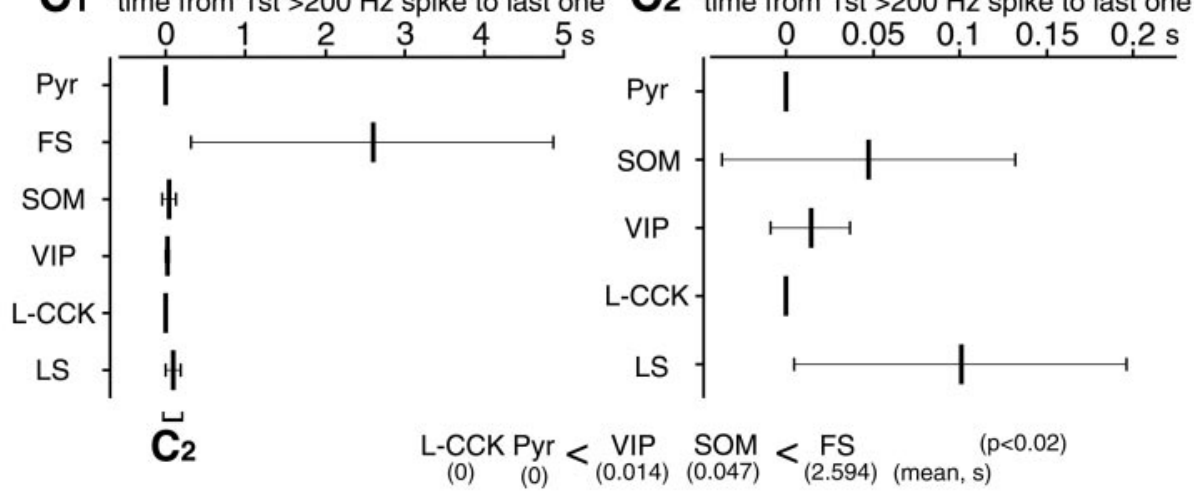

\section{Distinct firing patterns of nonpyramidal cell subtypes in each phase of synchronized depolarizations}

We investigated which responses each subtype of GABA cells exhibited during the cortical synchronized activities, including the rhythmic oscillation in comparison with pyramidal cells. GABAergic interneurons in the rat frontal cortex are divided mainly into two groups according to the intrinsic firing pattern in response to depolarizing current pulses (Kawaguchi and Kubota, 1996, 1998; Kawaguchi and Shindou, 1998): FS cells and non-FS cells (see Fig. 9). FS cells show abrupt episodes of nonadapting repetitive discharges of short-duration spikes in response to depolarizing currents and express parvalbumin, a calcium-binding protein. Other nonpyramidal cells are further divided into several subtypes by the intrinsic firing pattern and chemical markers. One subtype is late-spiking (LS) cells that exhibit the ramp-like depolarizing response before spike firing during a square wave current injection of threshold intensity. Other nonpyramidal cells (non-FS cells) than FS and LS cells are further classified on the basis of neuropeptide and calretinin (another calcium-binding protein) content. Somatostatin cells include Martinotti cells with ascending axonal arbors. On the other hand, VIP and/or calretinin cells include double bouquet and bipolar cells with descending axonal arbors. Large CCK cells have axonal arbors making multiple boutons on other cell bodies. We investigated the firing response of GABA cell subtypes on the depolarization shift, the initial discharge and FRLP of the long burst, compared with that of pyramidal cells. Unit spike discharges were recorded in a loosely cell-attached mode using pipettes for extracellular recordings during synchronized activities simultaneously monitored by the field potentials. After unit spike recording, the same cells identified visually were recorded in a whole-cell mode using patch electrodes, and their firing patterns to depolarizing current pulses were investigated. After fixation, recorded cells were identified immunohistochemically. Data were collected from 22 pyramidal cells, 13 FS cells including 4 parvalbumin cells, 7 somatostatin cells, 5 VIP cells, 5 large CCK cells, and 2 LS cells.

At depolarization shifts, nonpyramidal as well as pyramidal cells fired spikes. At the depolarization shift preceding the long burst, such as in Figure 1, Aiii and Biii, we measured the maximum frequency of spike discharges and spike number. The field potential and extracellularly recorded spikes of pyramidal, FS, and somatostatin cells are shown in Figure $5 A-C$. FS and somatostatin cells fired more vigorously than pyramidal cells. FS and somatostatin cells fired more spikes at higher frequency than pyramidal and large CCK cells (Fig. 5D,E).

Unit spike discharges and instantaneous spike frequencies of FS and large CCK cells during an initial discharge of the long burst are shown in Figure $6 A$. Scaling of spike frequency is different between FS and large CCK cells. FS cells continued high-frequency discharges longer than CCK cells. To quantify firing patterns, we measured the maximum firing frequency and the duration of high-frequency firing larger than $200 \mathrm{~Hz}$ (time 


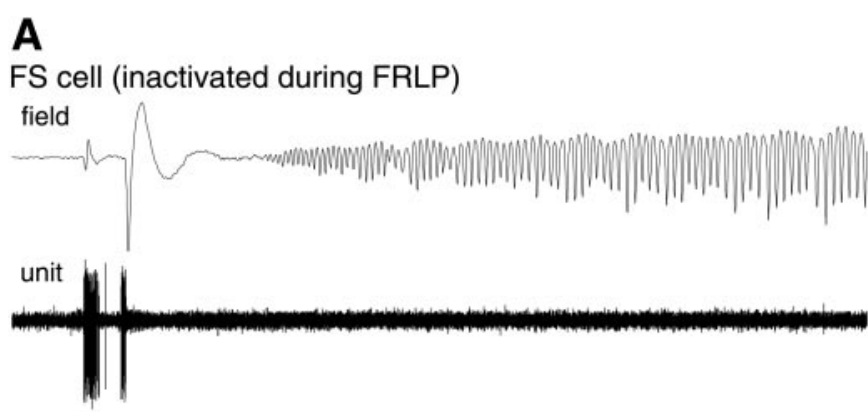

FS cell (non-inactivated during FRLP)
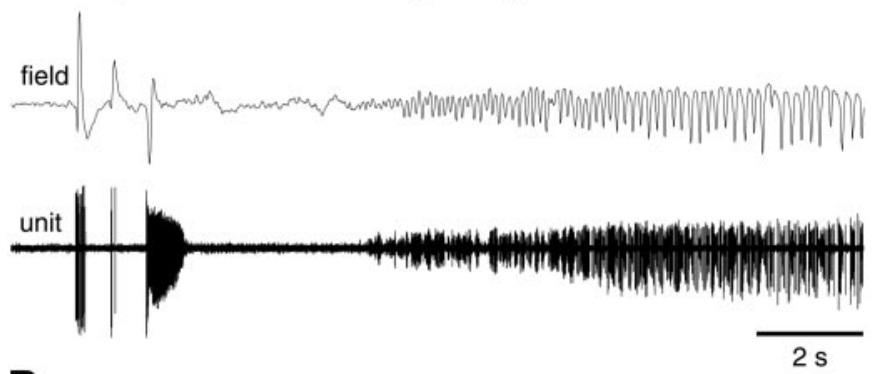

B

FS cell (inactivated during FRLP)

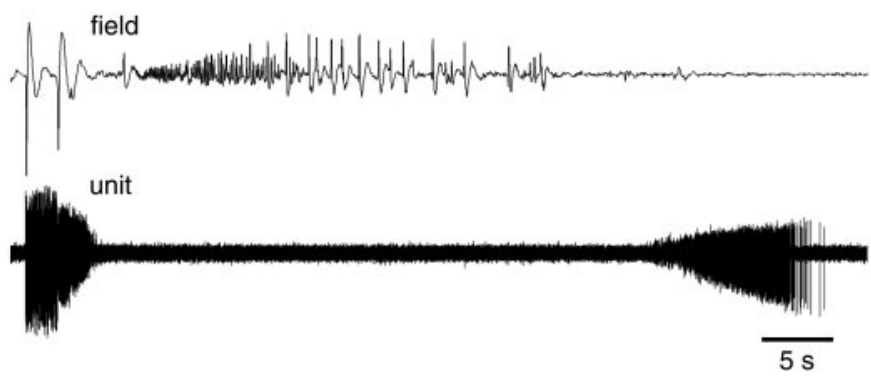

Figure 7. Spike discharges of FS cells during the FRLP. A, Some FS cells showed inactivation of spike firing (top), whereas other FS cells could fire spikes during the FRLP (bottom). B, After the initial discharge, the firings of this FS cell paused, but resumed spike firings, indicating the spike inactivation during the FRLP and afterdischarges.

from the first spike with firing frequency higher than $200 \mathrm{~Hz}$ to the last spike with frequency higher than $200 \mathrm{~Hz}$ ). For the maximum spike frequency shown in Figure $6 \mathrm{~B}$, FS cells fired at $330 \mathrm{~Hz}$, whereas somatostatin, VIP, and LS cells fired at $\sim 230-$ $250 \mathrm{~Hz}$. On the other hand, pyramidal cells and large CCK cells discharged at $130-150 \mathrm{~Hz}$. The duration of high-frequency firing that was faster than $200 \mathrm{~Hz}$ was shown in Figure $6 C$ (C2, expansion of the marked portion in $C 1$ ). Some FS cells fired spikes with higher frequency than $200 \mathrm{~Hz}$ for several seconds, whereas somatostatin, VIP, and LS cells show transient firings higher than 200 Hz. High-frequency $(>200 \mathrm{~Hz})$ firing in FS cells ceased mostly before the onset of the FRLP.

After initial discharges, nonpyramidal cells gradually began to modulate spike firings according to the FRLP cycle in a similar way to pyramidal cells. However, spike firings of some FS cells and a few somatostatin cells were inactivated during the FRLP because of strong depolarizations (Fig. 7A). After the firing pause during the FRLP and afterdischarges, FS cells could resume spike discharges, indicating the spike inactivation during the FRLP (Fig. 7B). Unit spikes of FS and large CCK cells during the FRLP were shown with the field potentials in Figure $8 A$. Both firings were modulated in discharge frequency according to the alternation of field potentials. The distributions of maximum spike frequencies for one fast run cycle are shown for the FS and large CCK cells. For the fast run, we measured the maximum spike frequencies during one cycle of the FRLP. In Figure $8 C$, the mean and SD of maximum frequencies for a cycle are plotted for neuron types. Pyramidal, somatostatin, and large CCK cells increased firing frequency to $30-50 \mathrm{~Hz}$ according to fast run cycle, whereas FS cell increased to $150 \mathrm{~Hz}$.

\section{Synchronized inhibitions during the depolarization shift} and long burst in parallel with excitations

Unit spike recordings from GABA cells indicated that not only strong excitations but also inhibitions occurred during the depolarization shift and long burst. To see inhibitory currents, spontaneous outward currents were recorded at a holding potential, 0 to $+10 \mathrm{mV}$. Inhibitory synaptic currents are shown with the field potential in Figure $9 A$. Because these outward currents were suppressed by a GABA-A receptor antagonist, bicuculline (10 $\mu \mathrm{M} ; n=15$ ), they were considered to be GABAergic currents. Inhibitory currents were induced during the depolarization shift and long burst. Inhibitory currents with field potentials during the long burst before and after bicuculline are expanded in Figure 9, $B$ and $C$, respectively.

By blocking GABA-A receptors after several long bursts occurred in $\mathrm{Mg}^{2+}$-free solution, the frequency of long bursts increased (burst interval, $310.4 \pm 121.7 \mathrm{sec}$ before bicuculline application, $43.0 \pm 28.7 \mathrm{sec}$ after application; $15.8 \pm 12.0 \% ; 10$ slices), and the duration of long bursts decreased (35.9 $\pm 10.8 \mathrm{sec}$ before application; $12.9 \pm 5.9 \mathrm{sec}$ after application; $36.4 \pm$ $16.5 \%$ ). The FRLP survived after inhibitory currents disappeared by bicuculline, although the duration and amplitude were shortened in most cases. These findings suggest that GABA-A receptor transmission is not necessary for induction of the long burst, including the FRLP, but it regulates the frequency and duration of the long burst and the amplitude and duration of the FRLP.

There was strong inhibition in conjunction with strong excitation at the initial discharge (Fig. 9B). After the robust inhibition reduced, the FRLP started. Strong inhibitory currents at the initial discharge were suppressed by bicuculline (Fig. 9C) $(n=$ 15). Initial strong inhibitions in the long burst seem to correspond to the period of high-frequency firings in FS cells. After bicuculline application, the amplitude of rhythmic synaptic currents during the FRLP reduced, and the relation between the peak of the outward currents and the FRLP cycle of the field potential changed (Fig. 9D,E) $(n=5)$. These suggest the rhythmic inhibitions during the FRLP.

Inhibitory postsynaptic currents from two pyramidal cells are shown with the field potential of depolarization shifts and a long burst in Figure $10 A$. Inhibitory currents occurred simultaneously between cortical cells during the depolarization shift and long burst (seven pairs). During the depolarization shifts, inhibitory currents were induced simultaneously with the field potential and took a similar time course (Fig. 10B). During the FRLP, inhibitory currents were generated at the similar phase of the field potential alternation between two cells (Fig. 10C,D). These suggest synchronous burst firing of GABA cells in the initial discharges and in the FRLP cycles. 

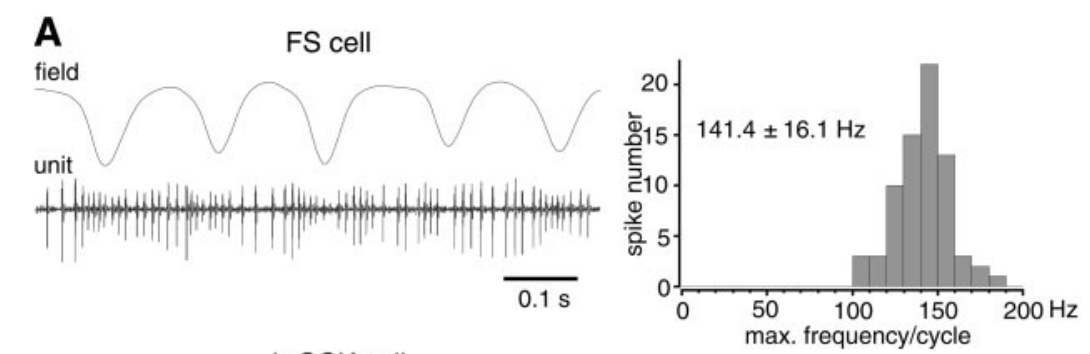

Figure 8. Firing patterns of cortical neuron types during fast run-like potential (FRLP). $A$, Unit spike discharges of an FS cell and a large CCK $(L-C C K)$ cell, and the distributions of maximum spike frequencies measured for each cycle of FRLP. Average of maximum frequencies per cycle for FRLP was $141 \mathrm{~Hz}$ for the FS cell and $47 \mathrm{~Hz}$ for the large CCK cell. $B$, Maximum frequency during one cycle of FRLP for pyramidal (Pyr) cells (26 FRLP from 22 cells), FS cells ( 9 FRLP from 5 cells), somatostatin cells (SOM) (6 FRLP from 5 cells), VIP cells (5 FRLP from 5 cells), L-CCK cells (8 FRLP from 5 cells), and late-spiking (LS) cells (3 FRLP from 2 cells). FS cells increased firing frequency to $\sim 150 \mathrm{~Hz}$ during the FRLP cycle, which was much faster than other types.
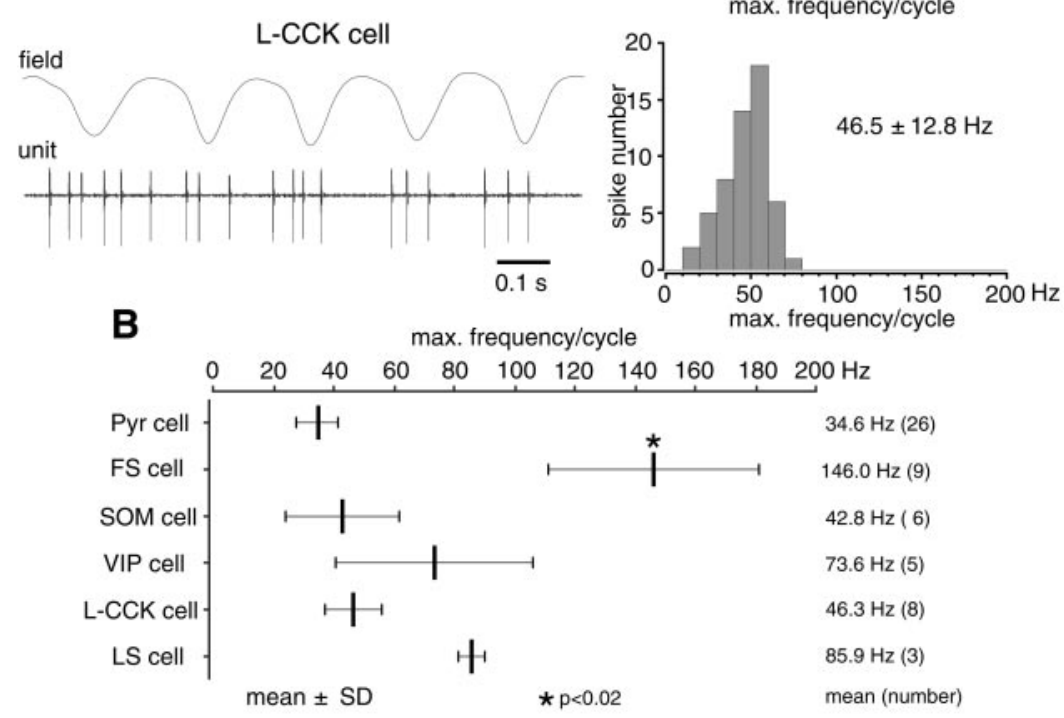

\section{DISCUSSION}

Figure 11 summarizes firing patterns of pyramidal cells and GABA cell subtypes during the long burst. After a series of depolarization shifts, the long burst, a seizure-like state, occurred. The long burst was composed of the initial discharges and FRLPs. Large inhibitory currents were induced at the initial discharge. After the strong inhibition decreased, the FRLP started. However, the periodical inhibition survived during the FRLP. The generation of FRLP was not dependent on GABAergic inhibition, although the duration was usually shortened by bicuculline.

At each phase of the synchronized activities, cortical neuron types exhibited distinct firing patterns. Pyramidal cells fired at maximum frequency of $25-55 \mathrm{~Hz}$ during the depolarizing phase of the FRLP cycle. FS cells fired at the highest frequency in the initial discharge, up to $400 \mathrm{~Hz}$, and could continue firing faster than $200 \mathrm{~Hz}$ for several seconds. In the FRLP, firings of FS cells were rhythmic up to $150 \mathrm{~Hz}$ and easily inactivated spike discharges because of strong depolarizations. In contrast, large CCK basket cells fired very similarly to pyramidal cell at each phase. Somatostatin and VIP cells fired faster than pyramidal cells at the initial discharge like depolarization shifts but showed similar firings to pyramidal cells during the FRLP.

\section{Firing patterns of cortical neuron types in depolarization shifts}

Synchronized depolarization shifts were induced in slices of the frontal cortex after bathing in $\mathrm{Mg}^{2+}$-free solution. The present experiments showed that FS cells and somatostatin cells fired more spikes at higher frequency than pyramidal cells and large CCK basket cells during the depolarization shifts. These depolarization shifts are similar to slow cortical oscillations that are generated within the cortex in vivo during urethane anesthesia and sleep (Steriade et al., 1993a,b, 1996). The previous studies suggest that the slow-rhythmic depolarizations are generated and self-sustained by recurrent excitations among pyramidal cells (Metherate and Ashe, 1993; Cowan and Wilson, 1994; Contreras et al., 1996; Sanchez-Vives and McCormick, 2000). This paper showed that strong GABAergic inhibitions occurred synchronously with excitations during the depolarization shift. These suggest that GABAergic cell subtypes and inhibitions can maintain appropriate recurrent excitations of pyramidal cells and suppress the transition from the depolarization shift to the long bursts.

Inhibitory postsynaptic potentials are induced in pyramidal cells by firing of FS cells and somatostatin cells (Deuchars and Thomson, 1995; Thomson et al., 1996; Thomson and Deuchars, 1997; Galarreta and Hestrin 1998; Reyes et al., 1998; Gibson et al., 1999). Both GABAergic cells innervate dendritic spines receiving another asymmetrical, probably excitatory, input on the head (Kawaguchi and Kubota, 1996, 1998; Kubota et al., 2000). FS and somatostatin cells may suppress different inputs to pyramidal cells because FS cells innervate dendrites, including thicker ones and spine necks, but somatostatin cells make synapses on thin dendritic branches and spine heads. FS cells include chandelier cells making GABAergic synapses almost exclusively on the axons (Kawaguchi, 1995; Kawaguchi and Kubota, 1998). The axo-axonic cells are likely to be crucial in modulating the generation of action potentials (Stuart and Sakmann, 1994). Considering more spikes with higher frequency at the depolarization shifts of FS and somatostatin cells than other types, these GABA cell subtypes may regulate the recurrent excitation through inhibitions on the inputs at spines and outputs from axon initial segments to prevent depolarizations of pyramidal cells to the point of spike inactivation. 

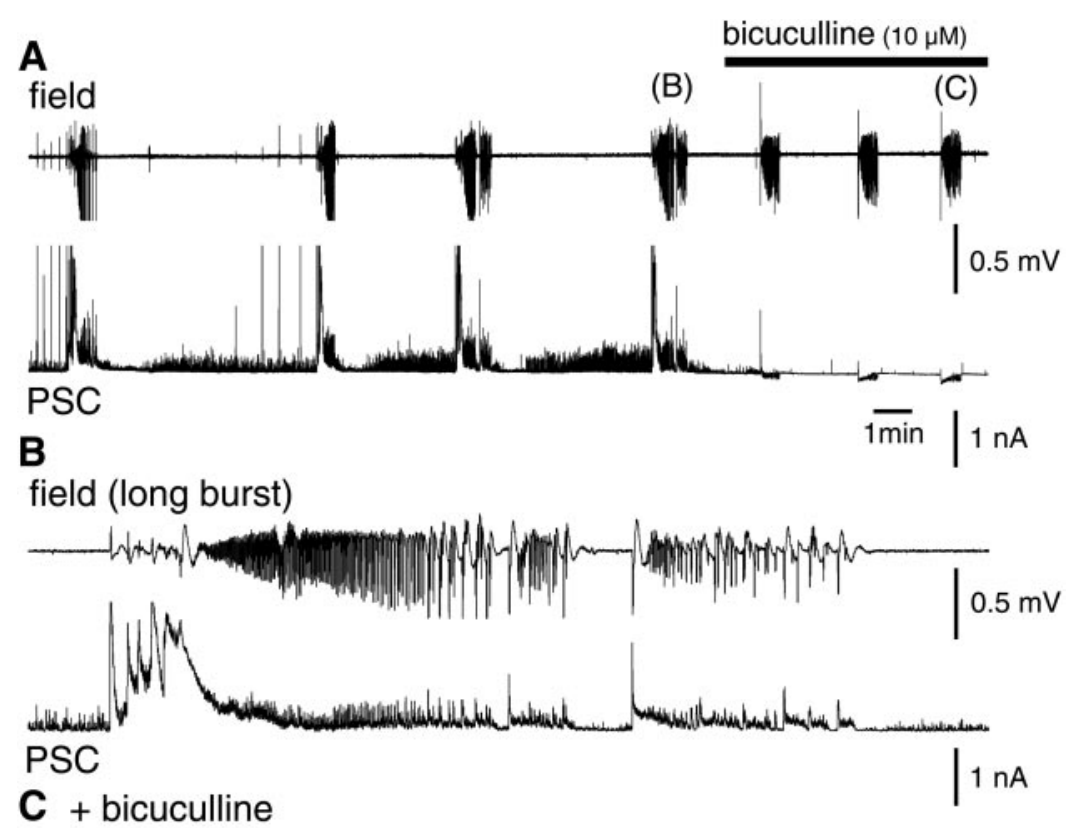

field (long burst)
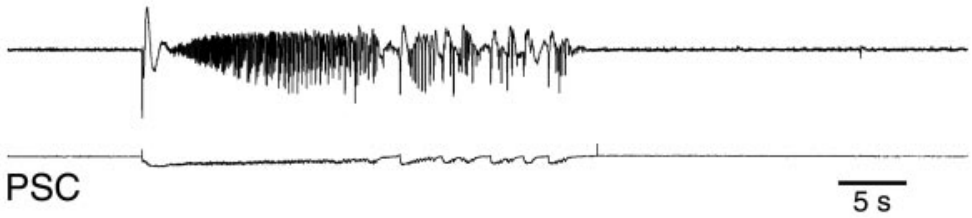

\section{D}

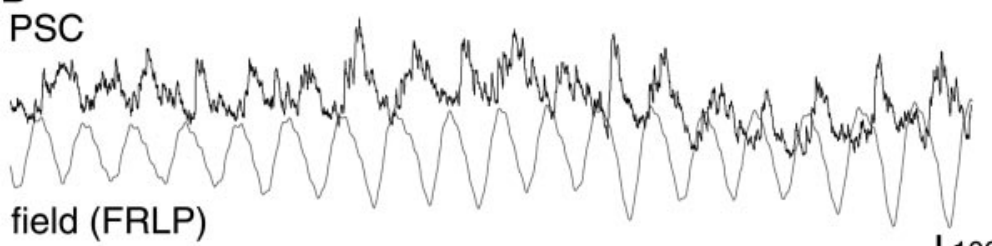

field (FRLP)

E + bicuculline

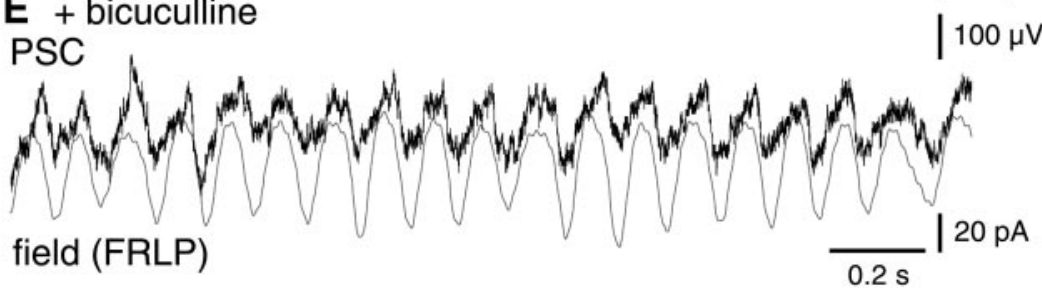

Figure 9. Induction of GABAergic IPSCs in the long burst. $A$, The increase of outward currents at $+10 \mathrm{mV}$ in a pyramidal cell was periodic and simultaneous with the field potential change. The field potential and the postsynaptic currents (PSC) are shown in the top and bottom, respectively. These outward currents were suppressed by application of $10 \mu \mathrm{M}$ bicuculline, indicating GABA-A IPSCs. $B$, Large IPSCs were induced in the initial discharge, but IPSCs also occurred during the FRLP. These are expanded from the part of traces shown in $A$. $C$, IPSCs during the long burst disappeared after the application of bicuculline, but inward currents were induced simultaneously with the field potential of the long burst. These are expanded from the part of traces in $A$. $D$, Currents during the FRLP (black) changed at the same periodicity as the alternation of field potential (gray). E, After bicuculline application, the alternating currents reduced in amplitude, and the relation between the peak of the outward currents and the FRLP cycle of the field potential changed.

\section{Synchronized and rhythmic firings in the long burst}

After the depolarization shifts occurred repeatedly, the long bursts appeared with abrupt strong depolarizations. The long bursts were synchronized among cortical cells, including both pyramidal and nonpyramidal cells. The initial depolarizations were much steeper than depolarization shifts, suggesting the synchronized firing of pyramidal cells. Regardless of the feedback and feedforward inhibitions by FS and somatostatin cells in re-entrant excitatory cortical circuits to prevent the positive feedback loop from overexcitation, simultaneous spike discharges may be induced in a group of pyramidal cells in the local region, and this rapid overexcitation propagates in the slice (Tsau et al., 1998). It remains to be solved how pyramidal cells in the local area can fire so synchronously (Connors, 1984; CastroAlamancos, 2000; Traub and Bibbig, 2000).

The maximum frequency of each neuron type in the initial discharges is considered to represent its fastest firing during cortical activation. At the initial discharges, FS cells fired more spikes with higher frequency than other types and could continue spike discharges at a frequency higher than $200 \mathrm{~Hz}$ for several seconds. Somatostatin, VIP, and LS cells fire transiently and exhibit firing higher than $200 \mathrm{~Hz}$, whereas pyramidal and large CCK cells do not. These results suggest that high-frequency firings could occur only in some neuron types, which are also different in their ability to continue fast firings. Fast oscillations higher than $200 \mathrm{~Hz}$ are observed in the cortex (Kandel and Buzsáki, 1997; Jones and Barth, 1999). These interneuron types, especially FS cells, are candidates for inducing high-frequency oscillations (Swadlow et al., 1998; Jones et al., 2000).

After the initial discharges, the rhythmic excitations on steady depolarization, FRLP $(\sim 6-10 \mathrm{~Hz})$, occurred in the long burst. The synchronous oscillation with the similar rhythm is induced in 


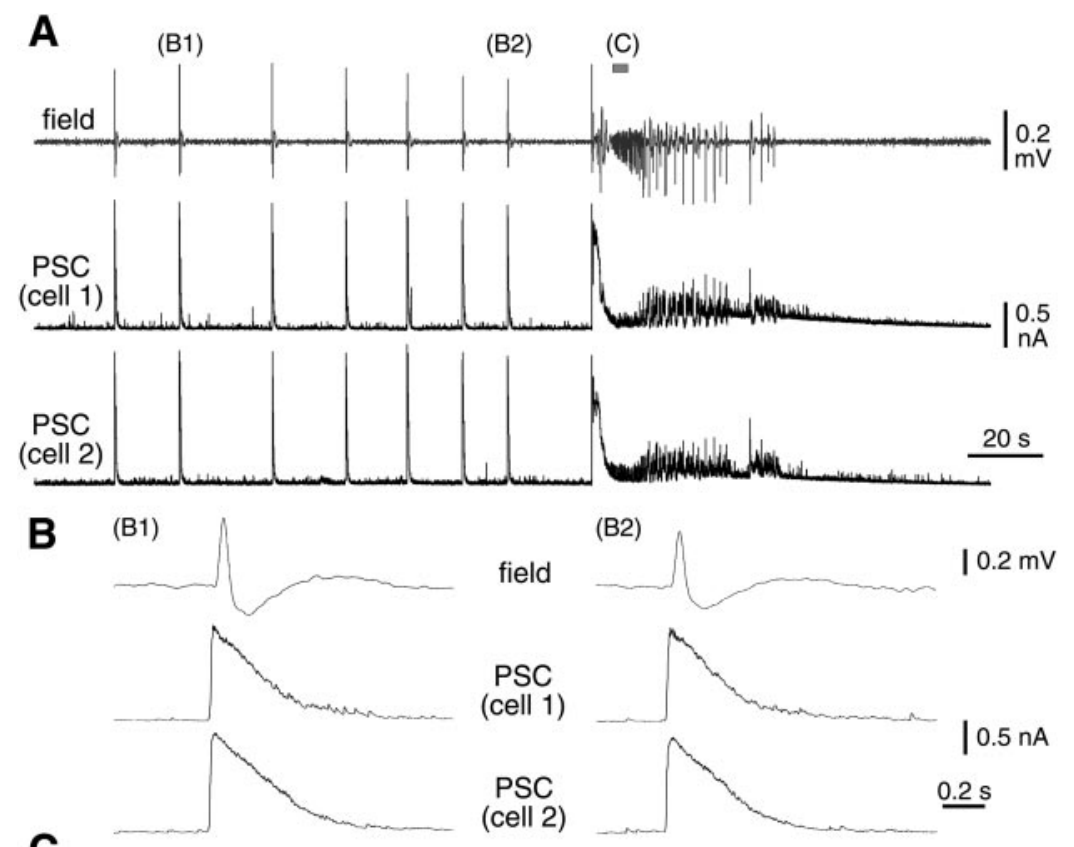

field, PSC (cell1)

Figure 10. IPSC occurrences between pyramidal cells at similar phases of the depolarization shift and long burst. $A$, The IPSCs in two pyramidal cells occurred similarly, coinciding with field potentials of the depolarization shift or initial discharge. The membrane potentials of pyramidal cells were clamped at $10 \mathrm{mV}$. B, Two pyramidal cells received synchronous IPSCs with similar time course at depolarization shifts. These depolarization shifts correspond to $B 1$ and $B 2$ shown in $A$. $C$, IPSCs in two cells were induced periodically at the similar phase of the FRLP cycle. These FRLPs correspond to $C$ shown in $A$. $D$, Some IPSCs occurred simultaneously during the FRLP. These field potentials and IPSCs correspond to D1 and $D 2$ shown in $C$.
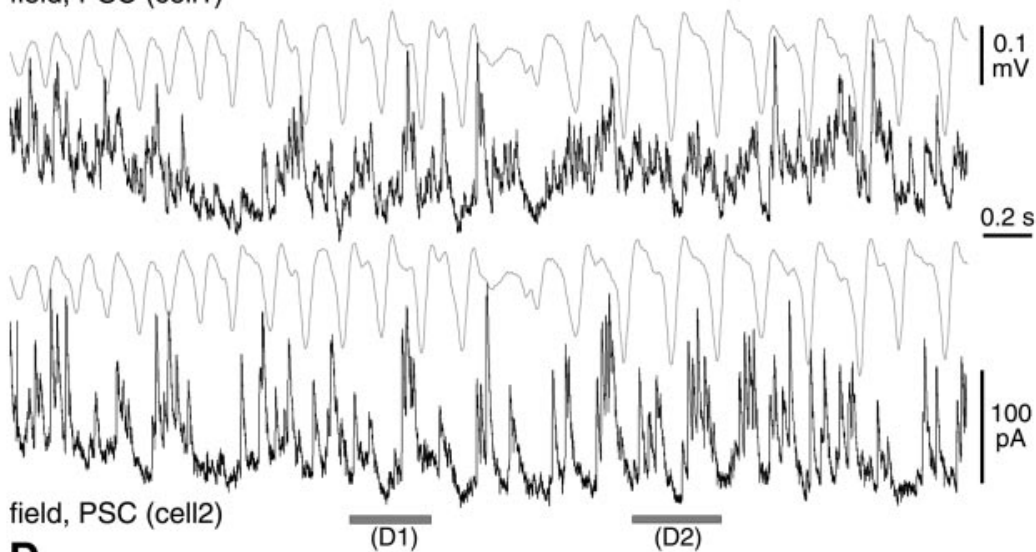

D

(D1)

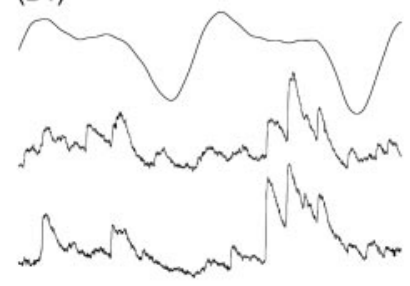

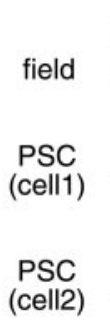

(D2)

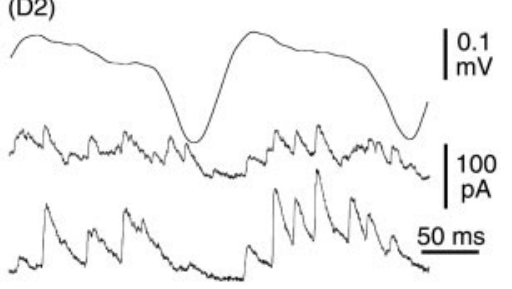

the slices of somatosensory cortex bathed in low $\mathrm{Mg}^{2+}$ solution (Silva et al., 1991; Flint and Connors, 1996; Wu et al., 1999), but the firing pattern of neuron types has not been investigated. Higher frequency firing than $200 \mathrm{~Hz}$ in most FS cells and the strong inhibitions ceased before the onset of the FRLP, indicating that continuous discharges of FS cells may suppress the cortical mechanism inducing the FRLP. During the FRLP, firing frequency of pyramidal cells reached $\sim 25-55 \mathrm{~Hz}$ repeatedly, according to the cycle of FRLP. Spikes synchronized temporally between pyramidal cells during certain periods of the FRLP. This synchronization of pyramidal cell firing during FRLP may be attributable to the common excitation, the rebound excitation after the common inhibition, the transmembrane depolarization caused by field effect, or intrinsic firing properties of pyramidal cells (Buhl et al., 1998; Bracci et al., 1999; Driesang and Pape, 2000). During the FRLP, FS cells often inactivated firing or increased the firing frequency to $150 \mathrm{~Hz}$ on each cycle, much faster than other subtypes. In contrast, large CCK cells showed similar firing patterns to pyramidal cells during the FRLP. Although both types innervate somata of pyramidal cells, they are very different in firing patterns during synchronization. These suggest that GABA cells innervating similar domains of cortical cells are composed of heterogeneous functional subgroups.

\section{Cortical GABA cell subtypes differentially involved in the cortical synchronized activities}

GABAergic nonpyramidal cells are very diverse in morphology, firing patterns to current pulses, dynamics of synaptic transmis- 


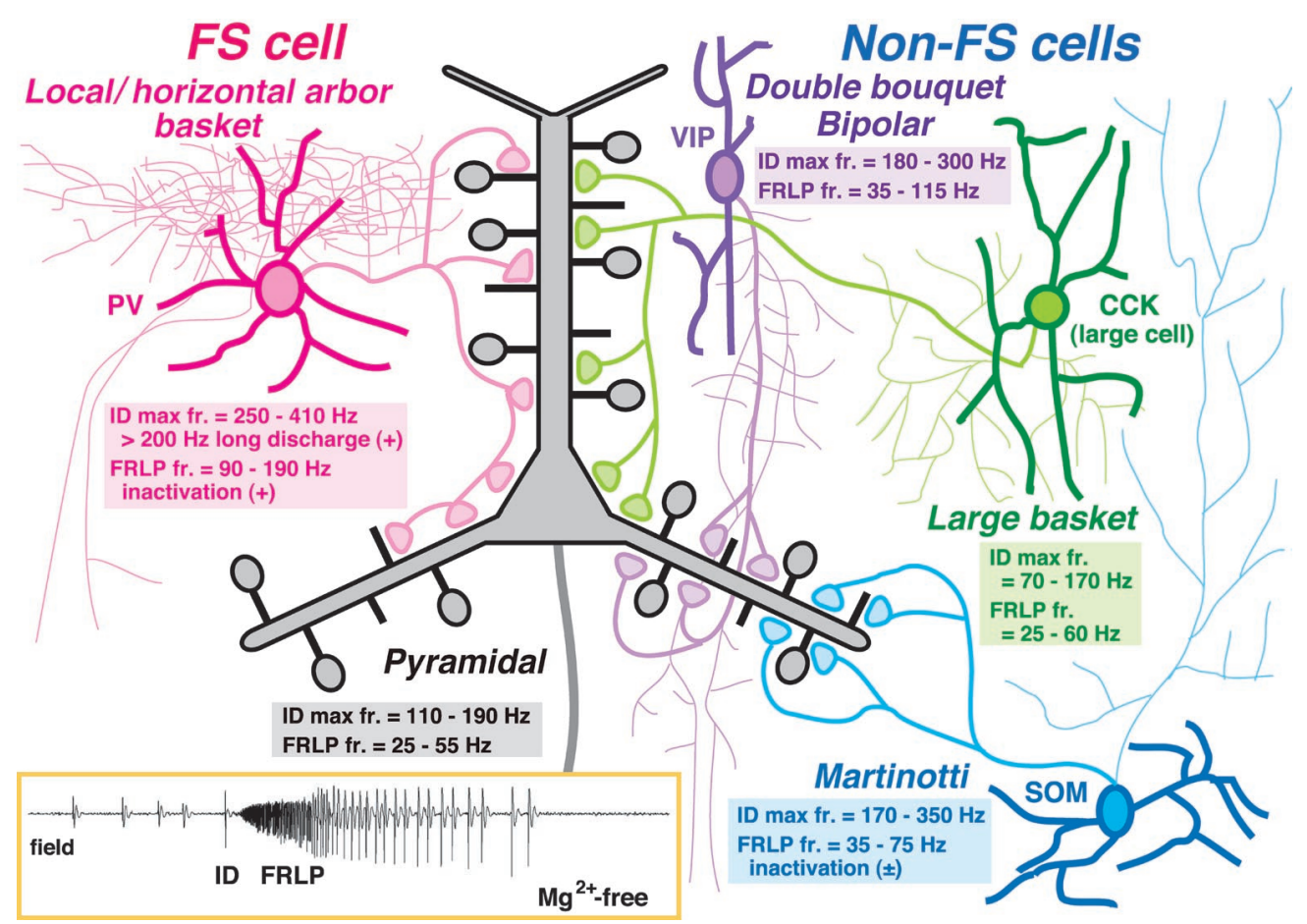

Figure 11. Summary of firing patterns of cortical neuron types during the long burst, induced by omission of extracellular $\mathrm{Mg}^{2+}$. ID max $f r$., Maximum spike frequency during the initial discharges; FRLP fr., maximum spike frequency during a FRLP cycle. Frequency ranges observed in this experiment are shown. Some FS and somatostatin cells showed inactivation of spike firing during the FRLP. FS cells could fire spikes for several seconds with higher frequency than $200 \mathrm{~Hz}$ during the initial discharges. Recording temperature, $30^{\circ} \mathrm{C}$. Protrusions from dendrites from pyramidal cells are spines, but excitatory synapses on the spine heads are omitted. $P V$, Parvalbumin; $S O M$, somatostatin, $I D$, initial discharges. Inset, field potential recording. sion, and expressed substances (Kawaguchi and Kubota, 1997; Cauli et al., 2000; Gupta et al., 2000). To understand the roles of GABA cell subtypes, it is important to know how each subtype responds to the synchronized excitation and the oscillation that the cortical circuits generate (Beierlein et al., 2000; Pike et al., 2000). Firing frequency of a neuron is determined by the synaptic input pattern and the intrinsic frequency preference (Hutcheon and Yarom, 2000; Pike et al., 2000), indicating that firing patterns of GABA cell subtypes need to be investigated by the physiological inputs generated by the intracortical circuitry, in addition to the depolarizing current pulses (Connors and Gutnick, 1990; Kawaguchi and Shindou, 1998; Gupta et al., 2000). The present results concerning spike firings during cortical synchronized activities, combined with the previous chemical, morphological, and physiological characterization, suggest the functional subgroups of GABAergic cells in the rat frontal cortex (Fig. 11).

\section{Fast-spiking cells}

FS cells may sense the excitation strength of local circuits and inhibit the recurrent excitation loop to maintain the transient depolarization of pyramidal cells, although the recurrent excitations that are larger than some strength point may overcome these inhibitions and induce the long bursts. FS cells may also be involved in high-frequency rhythm $(>200 \mathrm{~Hz})$ used for synchronized firing of pyramidal cells in the local area. The discharge ability at the highest frequency and the inactivation tendency during the long burst suggest that firings of FS cells are tuned for a certain strength of cortical excitation.

\section{Non-FS cells}

Somatostatin cells may regulate the recurrent excitation loop to inhibit excitatory inputs on spines of pyramidal cells. Stronger excitation of local circuits is more necessary for continuous firing of VIP cells and large CCK cells than somatostatin cells. VIP cells and large CCK cells are considered to make important roles for rhythmic firing of cortical cells during strong continuous depolarizations. Firing patterns of large CCK basket cells are most similar to those of pyramidal cells. Because large CCK cells are basket cells innervating somata with multiple boutons, they may make pyramidal cells fire with the same rhythmicity.

The cerebral cortex has the ability to self-excite at several frequencies. The present experiments suggest that the firing threshold, frequency, and inactivation for cortical cells are dependent not only on the strength and temporal pattern of synchronized depolarization but also on the neuron subtype.

\section{REFERENCES}

Amitai Y, Connors BW (1995) Intrinsic physiology and morphology of single neurons in neocortex. In: Cerebral cortex, Vol 11, The barrel cortex of rodents (Jones EG, Diamond IT, eds), pp 299-331. New York: Plenum.

Beierlein M, Gibson JR, Connors BW (2000) A network of electrically coupled interneurons drives synchronized inhibition in neocortex. Nat Neurosci 3:904-910.

Bracci E, Vreugdenhil M, Hack SP, Jefferys JGR (1999) On the synchronizing mechanisms of tetanically induced hippocampal oscillations. J Neurosci 19:8104-8113.

Buhl EH, Tamas G, Fisahn A (1998) Cholinergic activation and tonic excitation induce persistent gamma oscillations in mouse somatosensory cortex in vitro. J Physiol (Lond) 513:117-126.

Castro-Alamancos MA (2000) Origin of synchronized oscillations induced by neocortical disinhibition in vivo. J Neurosci 20:9195-9206.

Cauli B, Porter JT, Tsuzuki K, Lambolez B, Rossier J, Quenet B, Audinat E (2000) Classification of fusiform neocortical interneurons based on unsupervised clustering. Proc Natl Acad Sci USA 97:6144-6149.

Connors BW (1984) Initiation of synchronized neuronal bursting in neocortex. Nature 310:685-687.

Connors BW, Gutnick MJ (1990) Intrinsic firing patterns of diverse neocortical neurons. Trends Neurosci 13:99-104.

Contreras D, Timofeev I, Steriade M (1996) Mechanisms of long-lasting hyperpolarizations underlying slow sleep oscillations in cat corticothalamic networks. J Physiol (Lond) 494:251-264.

Cowan RL, Wilson CJ (1994) Spontaneous firing patterns and axonal projections of single corticostriatal neurons in the rat medial agranular cortex. J Neurophysiol 71:17-32.

DeFelipe J (1997) Types of neurons, synaptic connections and chemical characteristics of cells immunoreactive for calbindin-D28K, parvalbumin and calretinin in the neocortex. J Chem Neuroanat 14:1-19.

Deuchars J, Thomson AM (1995) Single axon fast inhibitory postsynaptic potentials elicited by a sparsely spiny interneuron in rat neocortex. Neuroscience 65:935-942. 
Driesang RB, Pape HC (2000) Spike doublets in neurons of the lateral amygdala: mechanisms and contribution to rhythmic activity. NeuroReport 11:1703-1708.

Flint AC, Connors BW (1996) Two types of network oscillations in neocortex mediated by distinct glutamate receptor subtypes and neuronal populations. J Neurophysiol 75:951-957.

Galarreta M, Hestrin S (1998) Frequency-dependent synaptic depression and the balance of excitation and inhibition in the neocortex. Nat Neurosci 1:587-594.

Gibson JR, Beierlein M, Connors BW (1999) Two networks of electrically coupled inhibitory neurons in neocortex. Nature 402:75-79.

Gupta A, Wang Y, Markram H (2000) Organizing principles for a diversity of GABAergic interneurons and synapses in the neocortex. Science 287:273-278.

Hegstad E, Langmoen IA, Hablitz JJ (1989) Zinc and glycine do not modify low-magnesium-induced epileptiform activity in the immature neocortex in vitro. Epilepsy Res 3:174-177.

Hutcheon B, Yarom Y (2000) Resonance, oscillation and the intrinsic frequency preferences of neurons. Trends Neurosci 23:216-222.

Jones EG (2000) Microcolumns in the cerebral cortex. Proc Natl Acad Sci USA 97:5019-5021.

Jones MS, Barth DS (1999) Spatiotemporal organization of fast $(>200$ $\mathrm{Hz}$ ) electrical oscillations in rat vibrissa/barrel cortex. J Neurophysiol 82:1599-1609.

Jones MS, MacDonald KD, Choi BJ, Dudek FE, Barth DS (2000) Intracellular correlates of fast $(>200 \mathrm{~Hz})$ electrical oscillations in rat somatosensory cortex. J Neurophysiol 84:1505-1518.

Kandel A, Buzsáki G (1997) Cellular-synaptic generation of sleep spindles, spike-and-wave discharges, and evoked thalamocortical responses in the neocortex of the rat. J Neurosci 17:6783-6797.

Kawaguchi Y (1995) Physiological subgroups of nonpyramidal cells with specific morphological characteristics in layer II/III of rat frontal cortex. J Neurosci 15:2638-2655.

Kawaguchi Y (1997) Selective cholinergic modulation of cortical GABAergic cell subtypes. J Neurophysiol 78:1743-1747.

Kawaguchi Y, Kubota Y (1996) Physiological and morphological identification of somatostatin- or vasoactive intestinal polypeptide-containing cells among GABAergic cell subtypes in rat frontal cortex. J Neurosci 16:2701-2715.

Kawaguchi Y, Kubota Y (1997) GABAergic cell subtypes and their synaptic connections in rat frontal cortex. Cereb Cortex 7:476-486.

Kawaguchi Y, Kubota Y (1998) Neurochemical features and synaptic connections of large physiologically-identified GABAergic cells in the rat frontal cortex. Neuroscience 85:677-701.

Kawaguchi Y, Shindou T (1998) Noradrenergic excitation and inhibition of GABAergic cell types in rat frontal cortex. J Neurosci 18:6963-6976.

Kubota Y, Karube F, Suzuki K, Kawaguchi Y (2000) Synaptic connection patterns of fast-spiking cells, Martinotti cells and double bouquet cells in the rat frontal cortex. Soc Neurosci Abstr 26:37.18.

Metherate R, Ashe JH (1993) Ionic flux contributions to neocortical slow waves and nucleus basalis-mediated activation: whole-cell recordings in vivo. J Neurosci 13:5312-5323.

Miles R (2000) Diversity in inhibition. Science 287:244-246.

Parra P, Gulyás AI, Miles R (1998) How many subtypes of inhibitory cells in the hippocampus? Neuron 20:983-993.
Pike FG, Goddard RS, Suckling JM, Ganter P, Kasthuri N, Paulsen O (2000) Distinct frequency preferences of different types of rat hippocampal neurones in response to oscillatory input currents. J Physiol (Lond) 529:205-213.

Ramón y Cajal S (1911) Histology of the nervous system, Vol 2. New York: Oxford UP.

Reyes A, Lujan R, Rozov A, Burnashev N, Somogyi P, Sakmann B (1998) Target-cell-specific facilitation and depression in neocortical circuits. Nat Neurosci 1:279-285.

Sanchez-Vives MV, McCormick DA (2000) Cellular and network mechanisms of rhythmic recurrent activity in neocortex. Nat Neurosci 3:1027-1034.

Silva LR, Amitai Y, Connors BW (1991) Intrinsic oscillations of neocortex generated by layer 5 pyramidal neurons. Science 251:432-435.

Somogyi P, Tamás G, Lujan R, Buhl EH (1998) Salient features of synaptic organisation in the cerebral cortex. Brain Res Brain Res Rev 26:113-135

Steriade M, Nunez A, Amzica F (1993a) A novel slow ( $<1 \mathrm{~Hz}$ ) oscillation of neocortical neurons in vivo: depolarizing and hyperpolarizing components. J Neurosci 13:3252-3265.

Steriade M, Nunez A, Amzica F (1993b) Intracellular analysis of relations between the slow $(<1 \mathrm{~Hz})$ neocortical oscillation and other sleep rhythms of the electroencephalogram. J Neurosci 13:3266-3283.

Steriade M, Contreras D, Amzica F, Timofeev I (1996) Synchronization of fast $(30-40 \mathrm{~Hz})$ spontaneous oscillations in intrathalamic and thalamocortical networks. J Neurosci 16:2788-2808.

Steriade M, Amzica F, Neckelmann D, Timofeev I (1998) Spike-wave complexes and fast components of cortically generated seizures. II. Extra- and intracellular patterns. J Neurophysiol 80:1456-1479.

Stuart GJ, Sakmann B (1994) Active propagation of somatic action potentials into neocortical pyramidal cell dendrites. Nature 367:69-72.

Swadlow HA, Beloozerova IA, Sirota MG (1998) Sharp, local synchrony among putative feed-forward inhibitory interneurons of rabbit somatosensory cortex. J Neurophysiol 79:567-582.

Thomson AM, Deuchars J (1997) Synaptic interactions in neocortical local circuits: dual intracellular recordings in vitro. Cereb Cortex 7:510-522.

Thomson AM, West DC (1986) N-methylaspartate receptors mediate epileptiform activity evoked in some, but not all, conditions in rat neocortical slices. Neuroscience 19:1161-1177.

Thomson AM, West DC, Hahn J, Deuchars J (1996) Single axon IPSPs elicited in pyramidal cells by three classes of interneurones in slices of rat neocortex. J Physiol (Lond) 496:81-102.

Traub RD, Bibbig A (2000) A model of high-frequency ripples in the hippocampus based on synaptic coupling plus axon-axon gap junctions between pyramidal neurons. J Neurosci 20:2086-2093.

Tsau Y, Guan L, Wu J-Y (1998) Initiation of spontaneous epileptiform activity in the neocortical slice. J Neurophysiol 80:978-982.

White EL (1989) Cortical circuits: synaptic organization of the cerebral cortex structure, function, and theory (White EL, Keller A, eds). Boston: Birkhäuser.

Wu J-Y, Guan L, Tsau Y (1999) Propagating activation during oscillations and evoked responses in neocortical slices. J Neurosci 19:50055015 . 